\title{
Cell-Specific Repressor or Enhancer Activities of Deaf-1 at a Serotonin 1A Receptor Gene Polymorphism
}

\author{
Margaret Czesak, ${ }^{\star}$ Sylvie Lemonde, ${ }^{\star}$ Erica A. Peterson, Anastasia Rogaeva, and Paul R. Albert \\ Ottawa Health Research Institute (Neuroscience), Department of Cellular and Molecular Medicine, University of Ottawa, Ottawa, Canada K1H 8M5
}

The serotonin-1A $\left(5-\mathrm{HT}_{1 \mathrm{~A}}\right)$ receptor is the primary somatodendritic autoreceptor that inhibits the activity of serotonergic raphe neurons and is also expressed in nonserotonergic cortical and limbic neurons. Alterations in 5- $\mathrm{HT}_{1 \mathrm{~A}}$ receptor levels are implicated in mood disorders, and a functional $\mathrm{C}(-1019) \mathrm{G} 5-\mathrm{HT}_{1 \mathrm{~A}}$ promoter polymorphism has been associated with depression, suicide, and panic disorder. We examined the cell-specific activity of identified transcription factors, human nuclear deformed epidermal autoregulatory factor- 1 (DEAF-1)-related (NUDR)/Deaf-1 and Hes5, at the 5-HT $1 \mathrm{~A}$ C(-1019) site. In serotonergic raphe RN46A cells, Deaf-1 and Hes5 repressed the 5- $\mathrm{HT}_{1 \mathrm{~A}}$ receptor gene at the $\mathrm{C}(-1019)$-allele but not the $\mathrm{G}(-1019)$-allele. However, in nonserotonergic cells that express $5-\mathrm{HT}_{1 \mathrm{~A}}$ receptors (septal SN48, neuroblastoma SKN-SH, and neuroblastoma/glioma NG108 - 15 cells), Deaf-1 enhanced 5-HT ${ }_{1 \mathrm{~A}}$ promoter activity at the C(-1019)-allele but not the G-allele, whereas Hes5 repressed in all cell types. The enhancer activity of Deaf-1 was orientation independent and competed out Hes5 repression. To test whether Deaf- 1 activity is intrinsic, the activity of a Gal4DBD (DNA binding domain)-Deaf-1 fusion protein at a heterologous Gal4 DNA element was examined. Gal4DBD-Deaf-1 repressed transcription in RN46A cells but enhanced transcription in SN48 cells, indicating that these opposite activities are intrinsic to Deaf-1. Repressor or enhancer activities of Deaf-1 or Gal4DBD-Deaf-1 were blocked by histone deacetylase inhibitor trichostatin A. Thus, the intrinsic activity of Deaf- 1 at the $5-\mathrm{HT}_{1 \mathrm{~A}}$ promoter is opposite in presynaptic versus postsynaptic neuronal cells and requires deacetylation. Cell-specific regulation by Deaf- 1 could underlie region-specific alterations in 5- $\mathrm{HT}_{1 \mathrm{~A}}$ receptor expression in different mood disorders.

Key words: 5- $\mathrm{HT}_{1 \mathrm{~A}}$ receptor; transcription factor; epigenetic; raphe; polymorphism; anxiety; major depressive disorder

\section{Introduction}

The serotonin system originates from neurons of the raphe nuclei that are negatively regulated by presynaptic $5-\mathrm{HT}_{1 \mathrm{~A}}$ autoreceptors (Penington et al., 1993; Bayliss et al., 1997). Postsynaptic $5-\mathrm{HT}_{1 \mathrm{~A}}$ receptors are also strongly expressed in brain regions that regulate mood and emotion (Törk, 1990; Jacobs and Azmitia, 1992). Anxiety, depression, and suicide appear to result from reduced serotonergic activity and antidepressants such as 5-HTselective reuptake inhibitors are thought to enhance serotonergic activity in part by desensitization of $5-\mathrm{HT}_{1 \mathrm{~A}}$ autoreceptors. In contrast, in midbrain tissue from depressed suicides, elevated levels of presynaptic 5-HT $\mathrm{HA}_{1 \mathrm{~A}}$ receptors were observed (Stockmeier et al., 1998), an alteration that would reduce serotonergic activity.

We postulated that upregulation of $5-\mathrm{HT}_{1 \mathrm{~A}}$ autoreceptors could be attributable to genetic alterations such as the $5-\mathrm{HT}_{1 \mathrm{~A}}$ $\mathrm{C}(-1019) \mathrm{G}$ functional promoter polymorphism. Several studies have associated the 5-HT ${ }_{1 \mathrm{~A}} \mathrm{G}(-1019)$ allele with major depres-

\footnotetext{
Received June 27, 2005; revised Dec. 20, 2005; accepted Dec. 22, 2005.

This research was supported by a grant from Canadian Institutes of Health Research (CIHR) (P.R.A.). M.C. received a Scholarship from the Ontario Graduate Scholarships in Science and Technology, S.L. was supported by a Studentship from CIHR, E.A.P. was partly supported by a summer internship award from the University of Ottawa Faculty of Medicine, A.R. received a K. M. Hunter/CIHR Studentship, and P.R.A. holds the Novartis/CIHR Michael Smith Chair in Neuroscience.

*M.C. and S.L. contributed equally to this work.

Correspondence should be addressed to Paul R. Albert at the above address. E-mail: palbert@uottawa.ca. D0I:10.1523/JNEUROSCI.2643-05.2006

Copyright $\odot 2006$ Society for Neuroscience $\quad 0270-6474 / 06 / 261864-08 \$ 15.00 / 0$
}

sion, suicide, panic disorder or decreased response to antidepressants (Lemonde et al., 2003, 2004b; Strobel et al., 2003; Serretti et al., 2004). The 5-HT ${ }_{1 \mathrm{~A}} \mathrm{G}(-1019)$ allele fails to bind identified repressors Deaf-1 and Hes5, leading to upregulation of autoreceptor expression. Consistent with a role of this site in $5-\mathrm{HT}_{1 \mathrm{~A}}$ autoreceptor regulation, an increase in $5-\mathrm{HT}_{1 \mathrm{~A}}$ autoreceptor expression in individuals with the G/G genotype has been observed (David et al., 2005; Parsey et al., 2006). Conversely, positron emission tomography imaging studies of depressed patients indicate decreased levels of postsynaptic $5-\mathrm{HT}_{1 \mathrm{~A}}$ receptors in the cortex and hippocampus (Drevets et al., 1999; Sargent et al., 2000; Albert and Lemonde, 2004). Furthermore, 5- $\mathrm{HT}_{1 \mathrm{~A}}$-null mice display increased anxiety-related behavior, which is rescued by early postnatal expression of the postsynaptic $5-\mathrm{HT}_{1 \mathrm{~A}}$ receptor in the forebrain (Gross et al., 2002). We therefore addressed whether the $\mathrm{C}(-1019) \mathrm{G}$ site might mediate differential regulation of the $5-\mathrm{HT}_{1 \mathrm{~A}}$ receptor in presynaptic versus postsynaptic cells.

In this study, the activity of Deaf- 1 at the $5-\mathrm{HT}_{1 \mathrm{~A}} \mathrm{C}(-1019)$ site was compared in serotonergic raphe cells and nonserotonergic neuronal or glial cells that express similar levels of endogenous $5-\mathrm{HT}_{1 \mathrm{~A}}$ receptors, including $\mathrm{SN} 48$ rat septal $\times$ mouse neuroblastoma cells, NG108 -15 rat glioma $\times$ mouse neuroblastoma cells, and SKN-SH human neuroblastoma cells (Charest et al., 1993; Ansorge et al., 2004; Fricker et al., 2005). Cell lines with intrinsic expression of 5- $\mathrm{HT}_{1 \mathrm{~A}}$ receptors were chosen to ensure the presence of relevant transcription factors necessary for $5-\mathrm{HT}_{1 \mathrm{~A}}$ receptor expression. We show that Deaf-1 enhances 5- $\mathrm{HT}_{1 \mathrm{~A}}$ promoter 
activity in the postsynaptic/glial cell models and that this enhancement is attenuated in the presence of the $\mathrm{C}(-1019) \mathrm{G}$ polymorphism. In contrast, Hes 5 represses $5-\mathrm{HT}_{1 \mathrm{~A}}$ gene transcription in all cell types examined. The cell-specific activity of Deaf-1 in 5- $\mathrm{HT}_{1 \mathrm{~A}}$ gene regulation could account for region-specific decreases in postsynaptic $5-\mathrm{HT}_{1 \mathrm{~A}}$ receptor levels reported in depressed patients.

\section{Materials and Methods}

Reporter constructs. The luciferase plasmids pGL3P-RE-1 (repressor element 1), pcDNA1-REST/NRSF (RE-1-silencing transcription factor/ neuron-restrictive factor), $5-\mathrm{HT}_{1 \mathrm{~A}}(\mathrm{C})(-1128$ to ATG), and 26bp-C(6)F, Gal4-DBD fusion constructs and X2G2P reporter constructs have been described previously (Lemonde et al., 2003, 2004a). Briefly, the luciferase plasmid $5-\mathrm{HT}_{1 \mathrm{~A}}(\mathrm{C})$ was obtained by insertion of a -1128 bp KpnIBssHII fragment of the human $5-\mathrm{HT}_{1 \mathrm{~A}}$ receptor gene into pGL3-Basic (Promega, Madison, WI) digested with KpnI and MluI. The 5- $\mathrm{HT}_{1 \mathrm{~A}}(\mathrm{G})$ construct was generated by unique site elimination mutagenesis (Amersham Biosciences, Piscataway, NJ) of C(-1019)G in 5- $\mathrm{HT}_{1 \mathrm{~A}}(\mathrm{C})$. Appropriate oligonucleotides of the 26 bp element flanked with CC and GG 3 '-overhangs were annealed, concatenated in six copies using T4 DNA ligase, blunted with Klenow, and subcloned into SmaI-cut pGL3promoter to generate $26 \mathrm{bp}-\mathrm{C}(6)$ and $26 \mathrm{bp}-\mathrm{G}(6)$. Full-length Deaf-1 was obtained by PCR amplification using the human brain Marathon-Ready cDNA kit (BD Biosciences, Mississauga, Ontario, Canada). The PCR product was subcloned in pGEM-T Easy vector (Promega) before subcloning in the EcoRI site of pcDNA3 (Invitrogen, San Diego, CA). The $26 \mathrm{bp}-\mathrm{C}(6) \mathrm{R}$ was generated by ligation of a NheI/XhoI blunted fragment, obtained from 26bp-C(6)F construct into pGL3B (Promega), digested by $\mathrm{SmaI}$. All plasmids were purified by $\mathrm{CsCl}$ equilibrium gradient centrifugation, quantified spectrophotometrically, and verified by dideoxynucleotide DNA sequencing.

Cell culture and transfection. Septal SN48, NG108-15, and SKN-SH neuroblastoma cells were grown in DMEM (Invitrogen BRL, Rockville, MD) supplemented with $10 \% \mathrm{v} / \mathrm{v}$ heat-inactivated fetal bovine serum at $37^{\circ} \mathrm{C}$ in $5 \% \mathrm{CO}_{2}$. Binding studies of crude membranes from these cells using $\left[{ }^{3} \mathrm{H}\right]-2$ (di- $n$-propylamino)tetralin revealed (mean \pm range; $n=2$ ) $3.0 \pm 0.5,8.3 \pm 1.6$, and $2.7 \pm 1.0 \mathrm{fmol} / \mathrm{mg}$ protein of $5-\mathrm{HT}_{1 \mathrm{~A}}$ receptor sites, respectively. RN46A cells ( $2.4 \pm 0.6 \mathrm{fmol} / \mathrm{mg} 5-\mathrm{HT}_{1 \mathrm{~A}}$ sites) (Kushwaha and Albert, 2005) were grown on Primaria six-well plates (Falcon, Franklin Lakes, NJ) in Neurobasal medium (Invitrogen BRL) supplemented with $10 \% \mathrm{v} / \mathrm{v}$ heat-inactivated fetal bovine serum, $0.1 \%$ PenStrep, and $0.04 \%$ of L-glutamine at $33^{\circ} \mathrm{C}$ in $5 \% \mathrm{CO}_{2}$ (Lemonde et al., 2003, 2004a). Media were changed 16-24 h before transfection. Except for the RN46A and SKN-SH cells, transfections were done using calcium phosphate coprecipitation as described previously (Charest et al., 1993) with $20 \mu \mathrm{g}$ of luciferase construct and $5 \mu \mathrm{g}$ of pCMV $\beta$ gal per $10 \mathrm{~cm}$ plate or with $10 \mu \mathrm{g}$ of luciferase-expressing vector, indicated amounts of pcDNA expression constructs or empty vector and $0.5 \mu \mathrm{g}$ of pCMV $\beta$ gal to normalize transfection efficiency, maintaining the total DNA transfected at $25 \mu \mathrm{g}$. Raphe RN46A cells and SKN-SH cells were transfected with 1:2 and 1:1.5 ratios, respectively, of plasmid:Lipofectamine2000 reagent (Invitrogen) using $10 \mu \mathrm{g} /$ plate of luciferase plasmid and equal amount of protein-expression constructs or empty vector and $2 \mu \mathrm{g} /$ plate pCMV $\beta$ gal. In some experiments, $200 \mathrm{~nm}$ trichostatin A (TSA) or vehicle $(0.75 \%$ ethanol $)$ was applied to the culture medium at the time of transfection.

Reporter assays. Luciferase and $\beta$-galactosidase assays were performed as described previously (Ou et al., 2000; Lemonde et al., 2003). Activities were obtained from at least three independent experiments in which triplicate transfections were performed and corrected for transfection efficiency by calculating the ratio of luciferase/ $\beta$-galactosidase activity and normalizing to vector-transfected extracts. Data are presented as mean $\pm \mathrm{SD}$. Statistical significance was evaluated using two-tailed unpaired $t$ test and 95\% confidence intervals with GraphPad Prism software (GraphPad, San Diego, CA) unless indicated otherwise.

Nuclear and cytosolic fractionation. Fractionation was adapted from methods described previously (Lemonde et al., 2003; Subramanian and
Chinnadurai, 2003; Zuccato et al., 2003). Cells $\left(10^{7}\right)$ were trypsinized and collected in $14 \mathrm{ml}$ of HEPES-buffered balanced salts plus EDTA buffer (118 mm NaCl, $4.6 \mathrm{~mm} \mathrm{KCl,} 10 \mathrm{~mm}$ D-glucose, 5 mм EDTA, $20 \mathrm{~mm}$ HEPES, pH 7.2), pelleted at $4^{\circ} \mathrm{C}$ for $4 \mathrm{~min}$ at $500 \times g$ and resuspended in $1 \mathrm{ml}$ of resuspension buffer ( $10 \mathrm{~mm} \mathrm{KCl}, 10 \mathrm{~mm}$ Na-HEPES, pH 7.6, 1.5 $\mathrm{mm} \mathrm{MgCl}_{2}$ ) and allowed to swell on ice for $10 \mathrm{~min}$. The resulting cells were collected by spinning for $10 \mathrm{~min}$ at $4^{\circ} \mathrm{C}$ at $500 \times g$ and the pellets lysed using $50 \mu \mathrm{l}$ of extraction buffer per $2-3 \times 10^{6}$ cells $(10 \mathrm{~mm} \mathrm{KCl}, 10$ mм Na-HEPES, pH 7.6, 1.5 mм $\mathrm{MgCl}_{2}$, 0.1\% NP-40, 0.5 mм DTT, 0.5 mu spermidine, $0.15 \mathrm{~mm}$ spermine, $1 \mathrm{~mm}$ PMSF, $1 \times$ Protease Inhibitor Cocktail (Roche Diagnostics, Welwyn Garden City, UK). Nuclear pellets were collected by centrifugation at $1000 \times g$ for $2 \mathrm{~min}$ at $4^{\circ} \mathrm{C}$ and washed three times using $1 \mathrm{ml}$ of wash buffer $(50 \mathrm{~mm} \mathrm{NaCl}, 20 \mathrm{~mm}$ Na-HEPES, $\mathrm{pH} 7.6,25 \%$ glycerin, $0.2 \mathrm{~mm}$ EDTA, $1.5 \mathrm{~mm} \mathrm{MgCl}_{2}, 0.5 \mathrm{~mm}$ DTT, $0.5 \mathrm{~mm}$ spermidine, $0.15 \mathrm{~mm}$ spermine, $1 \mathrm{~mm}$ PMSF, $1 \times$ Protease Inhibitor Cocktail) and lysed using $50 \mu$ l of nuclear extraction buffer per $2-3 \times 10^{6}$ cells ( $500 \mathrm{~mm} \mathrm{NaCl}, 20 \mathrm{~mm}$ Na-HEPES, pH 7.6, 25\% glycerin, $0.2 \mathrm{~mm}$ EDTA, $1.5 \mathrm{~mm} \mathrm{MgCl}_{2}$, $0.5 \mathrm{~mm}$ DTT, $0.5 \mathrm{~mm}$ spermidine, $0.15 \mathrm{~mm}$ spermine, $1 \mathrm{~mm}$ PMSF, $1 \times$ Protease Inhibitor Cocktail) and rotated for $30 \mathrm{~min}$ at $4^{\circ} \mathrm{C}$. The nuclear proteins were collected from the supernatant after centrifugation for $15 \mathrm{~min}$ at $16,000 \times g$ at $4^{\circ} \mathrm{C}$ to clear cell debris.

Western blot analysis. Nuclear or cytosolic proteins (50 $\mu \mathrm{g} /$ reaction) were separated by SDS-PAGE on a $12 \%$ gel, transferred to nitrocellulose membrane, and blocked using TBS containing 5\% dry milk and $0.02 \%$ Tween 20. Immunoreactive proteins were detected with rabbit antiDeaf-1 antibody (Lemonde et al., 2003) at a dilution of 1:5000 followed by a 1:2000 dilution of the secondary horseradish peroxidase-linked antirabbit antibody. Anti-histone 1 (nuclear marker) antibody (Upstate Biotechnology, Lake Placid, NY) was used at 1:1000 (Zuccato et al., 2003). Anti-c-Raf (cytosolic marker) antibody (BD Biosciences) was used at 1:3000 dilution (Brown et al., 2004).

Electrophoretic mobility shift assay. Sense and antisense oligonucleotides of the 26 bp Deaf-1 element (C-allele) with CC/GG 3'-overhangs were hybridized and labeled with $\left[\alpha-{ }^{32} \mathrm{P}\right]$-dCTP using Klenow fragment DNA polymerase (Ou et al., 2000). Nuclear extract ( $5 \mu \mathrm{g} /$ reaction) was preincubated with or without competitor DNA in a $20 \mu \mathrm{l}$ reaction containing gel-shift DNA binding buffer (20 mM HEPES, $0.2 \mathrm{~mm}$ EDTA, 0.2 mм EGTA, $100 \mathrm{~mm} \mathrm{KCl,} \mathrm{5 \%} \mathrm{glycerol,} \mathrm{and} 2 \mathrm{~mm}$ DTT, pH 7.9), $250 \mathrm{ng}$ of herring sperm DNA, at room temperature for $20 \mathrm{~min}$. Unlabeled doubled-stranded polyomavirus enhancer activator 3 (PEA3) sequences (5-GGGATCCAGGAAGTGA-3) were used as nonspecific competitor and were electrophoresed on a nondenaturing 5\% acrylamide/Trisglycine gel at $4^{\circ} \mathrm{C}$ to resolve protein-DNA complexes. For SKN-SH extracts, the probe was trapped in poorly migrating nonspecific protein/ DNA aggregate that was not competed by specific oligonucleotide.

\section{Results}

\section{Cell- and allele-specific activity of Deaf- 1 at the $5-\mathrm{HT}_{1 \mathrm{~A}}$ promoter}

The transcriptional activity of Deaf- 1 and Hes5 was compared in serotonergic (RN46A) (Fig. 1A) and nonserotonergic (SN48, NG108-15, and SKN-SH) (Fig. $1 B$ ) $5-\mathrm{HT}_{1 \mathrm{~A}}$ receptor-positive neuronal cells cotransfected with $\mathrm{C}(-1019)$ or $\mathrm{G}(-1019)$ human $5-\mathrm{HT}_{1 \mathrm{~A}}$ promoter-luciferase reporter constructs $\left[5-\mathrm{HT}_{1 \mathrm{~A}}(\mathrm{C})\right.$ or $(\mathrm{G})$, respectively]. Cell lines with intrinsic expression of 5- $\mathrm{HT}_{1 \mathrm{~A}}$ receptors were chosen to ensure the presence of relevant transcription factors necessary for $5-\mathrm{HT}_{1 \mathrm{~A}}$ receptor expression. As previously observed in RN46A raphe cells, both Deaf- 1 and Hes5 repressed the activity of the $5-\mathrm{HT}_{1 \mathrm{~A}}(\mathrm{C})$ construct by $50 \%$ but had no effect at the $5-\mathrm{HT}_{1 \mathrm{~A}}(\mathrm{G})$ construct, but there was no significant difference in basal activity between the two alleles. In contrast, in SN48 and NG108-15, there was a 70\% reduction in basal activity of $5-\mathrm{HT}_{1 \mathrm{~A}}(\mathrm{G})$ compared with the $5-\mathrm{HT}_{1 \mathrm{~A}}(\mathrm{C})$ construct, with a smaller but significant reduction in SKN-SH cells (Fig. $1 B$ ). Furthermore, cotransfection of Deaf- 1 significantly increased the activity of $5-\mathrm{HT}_{1 \mathrm{~A}}(\mathrm{C})$ construct but not the $5-\mathrm{HT}_{1 \mathrm{~A}}(\mathrm{G})$ construct. Deaf-1 also enhanced $5-\mathrm{HT}_{1 \mathrm{~A}}$ promoter activity in $5-\mathrm{HT}_{1 \mathrm{~A}}$ - 
A

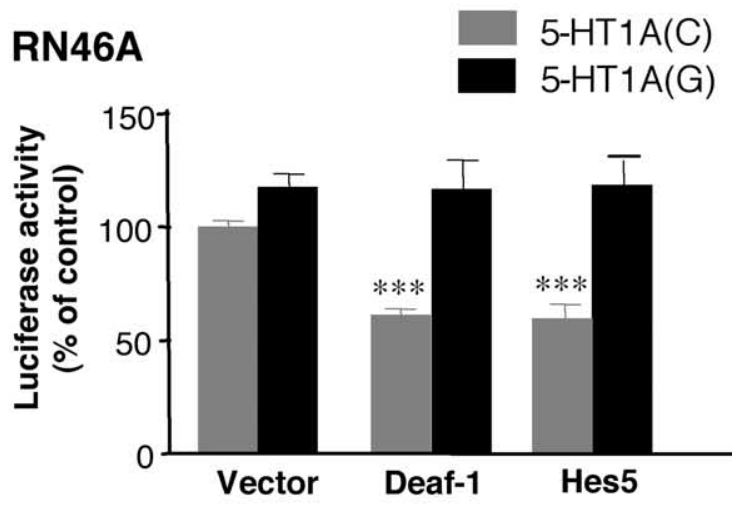

B

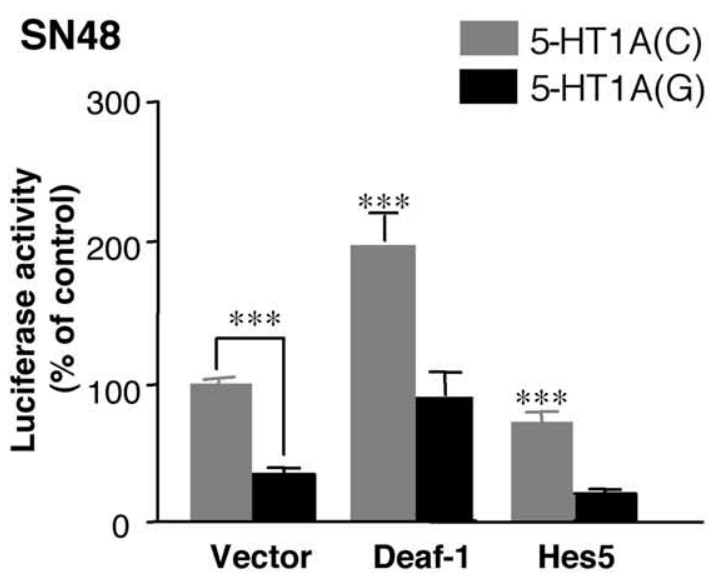

NG108-15

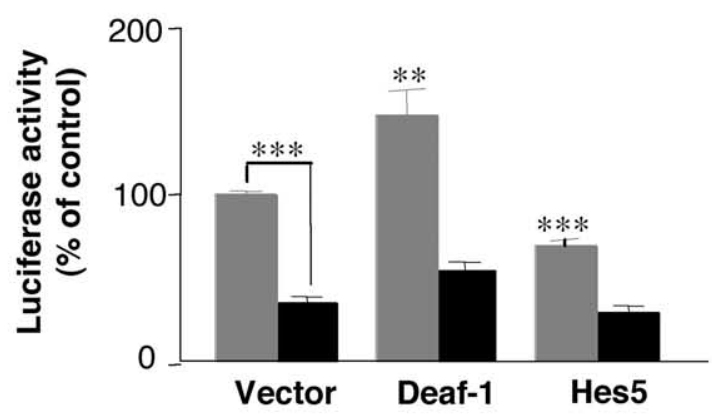

\section{SKN-SH}

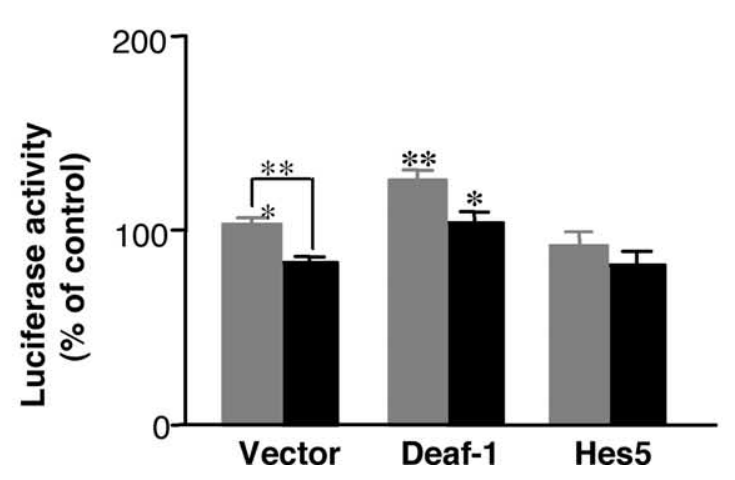

expressing H19-7 rat hippocampal cells (data not shown). In contrast, Hes5 mediated a significant repression of the $5-\mathrm{HT}_{1 \mathrm{~A}}(\mathrm{C})$ but not G-allele in SN48 and NG108-15 cells. Thus, in several models of postsynaptic or glial $5-\mathrm{HT}_{1 \mathrm{~A}}$ gene expression, Deaf- 1 enhanced 5- $\mathrm{HT}_{1 \mathrm{~A}}$ transcriptional activity at the $\mathrm{C}(-1019)$ site, whereas it repressed $5-\mathrm{HT}_{1 \mathrm{~A}}$ transcription in serotonergic raphe cells.

\section{Deaf- 1 expression and localization}

Because endogenous Deaf- 1 could influence basal 5- $\mathrm{HT}_{1 \mathrm{~A}}$ transcription, Deaf-1 protein was detected in nuclear and cytosolic extracts by Western blot using a specific antibody, which recognized a single $60 \mathrm{kDa}$ species (Lemonde et al., 2003) (Fig. 2A). Levels of Deaf- 1 were highest in nuclear extracts from RN46A cells, with low or undetectable levels in SN48, SKN-SH, and NG108-15 nuclear fractions. In contrast, Deaf-1 was abundantly expressed in cytosolic extracts from these cell types. Markers specific for nuclear (H1-histone) or cytosolic (c-Raf protein) fractions indicated undetectable cross-contamination between fractions and similar protein loading among cell types. The DNA binding activity of Deaf- 1 in nuclear fractions was determined (Fig. 2B). A specific Deaf-1/DNA complex with labeled human Deaf-1 element (C-allele) was observed that was completely competed with excess unlabeled Deaf-1 element $(\mathrm{Sp})$ but weakly competed by unrelated PEA-3 site primers (NSp). Deaf-1 binding activity paralleled the nuclear protein content identified by Western blot (Fig. 2A), greatest in RN46A cells and weak but detectable in SN48, SKN-SH, and NG108-15 cells. Therefore, endogenous Deaf- 1 from rat or human nuclei binds to the $5-\mathrm{HT}_{1 \mathrm{~A}}$ site in accordance with its protein abundance. The abundance of nuclear Deaf-1 in RN46A cells suggests that Deaf-1 may repress endogenous $5-\mathrm{HT}_{1 \mathrm{~A}}$ receptor expression.

Deaf-1 enhancer/repressor activity at the C(-1019) Deaf-1 site To determine whether the 26 bp Deaf- 1 element is sufficient to confer cell-specific activity of Deaf- 1 , the activity of Deaf- 1 at a reporter construct containing the Deaf- 1 element (in six copies) placed upstream of the SV40 promoter [26bp-C(6)] was compared in RN46A and SN48 cells (Fig. 3). In RN46A cells, Deaf-1 almost completely inhibited transcriptional activity, whereas in SN48 cells, Deaf-1 mediated enhancer activity. Repressor or enhancer activity of Deaf-1 was observed in forward or reverse orientations of Deaf-1 sites, as expected for orientationindependent enhancer or repressor activity. In cells transfected with a control vector lacking Deaf- 1 sites, Deaf- 1 had no effect (data not shown). Therefore, the 26-bp Deaf- 1 element is sufficient to confer cell-specific Deaf-1-mediated repressor or enhancer activity.

Regulation of the $5-\mathrm{HT}_{1 \mathrm{~A}}$ promoter could involve interactions

$\leftarrow$

Figure 1. Cell type-dependent activity of Deaf- 1 at the $5-\mathrm{HT}_{1 \mathrm{~A}} \mathrm{C}(-1019)$ site. Constructs containing the C(-1019) or $\mathrm{G}(-1019)$ allele of the human $5-\mathrm{HT}_{1 \mathrm{~A}}$ promoter ( $-1128 \mathrm{bp}$ to ATG) fused to luciferase $\left[5-\mathrm{HT}_{1 \mathrm{~A}}(\mathrm{C})\right.$ and $5-\mathrm{HT}_{1 \mathrm{~A}}(\mathrm{G})$, respectively] were cotransfected with vector ( $p$ DDNA3), Deaf-1, or Hes5 expression plasmids as indicated in 5- $\mathrm{HT}_{1 \mathrm{~A}}$-expressing neuronal cell lines: rat raphe RN46A (A), mouse septal SN-48, neuroblastoma-glioma NG108 -15, or human SKN-SH neuroblastoma cells $(\boldsymbol{B})$. Adjusted luciferase activity was corrected for transfection efficiency by calculating the ratio of luciferase activity/ $\beta$-galactosidase activity and normalized to control ( $p c D N A 3)$ transfections. Data are presented as mean $\pm S D$ of triplicate samples collected from at least three independent experiments as indicated. Statistical analysis compared with vector control (for Deaf-1 and Hes5) was determined by one-way ANOVA; significant differences between $C$ and $\mathrm{G}$ alleles were evaluated by unpaired $t$ test with two-tailed $p$ values $\left({ }^{* *} p \leq 0.01 ;{ }^{* * *} p \leq 0.001\right)$. 
A

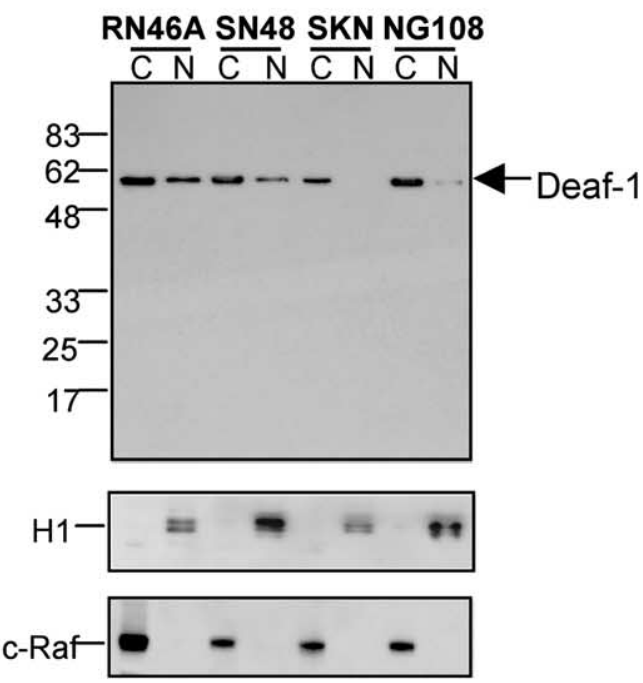

B
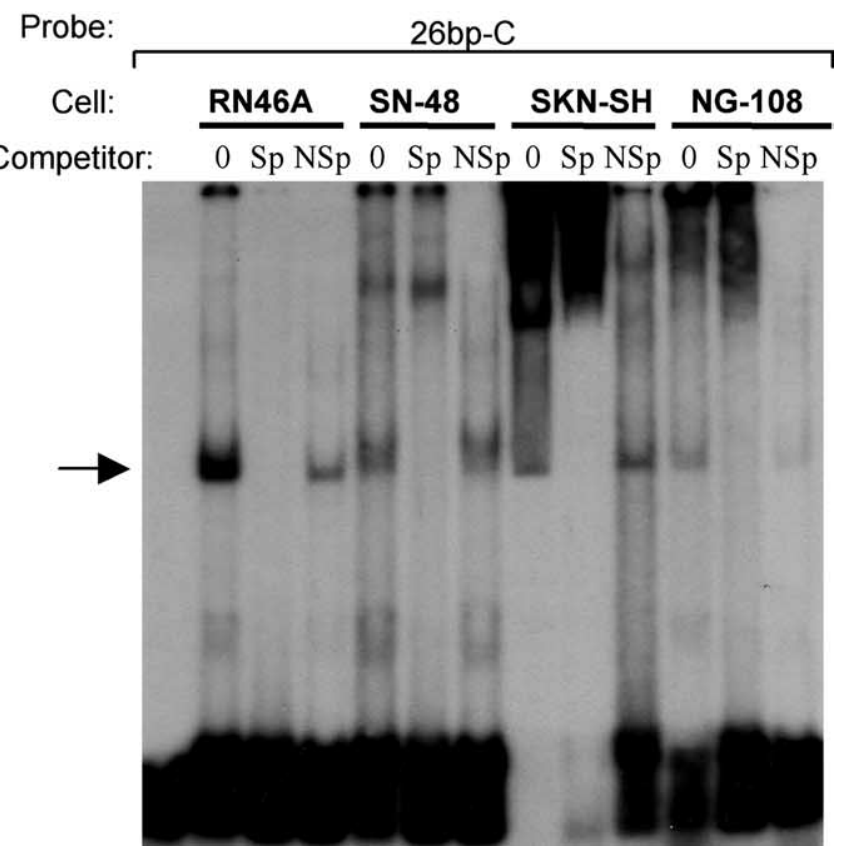

Figure 2. Endogenous Deaf- 1 protein expression and DNA binding activity. $\boldsymbol{A}$, Deaf- 1 localization. Nuclear (N) and cytosolic (C) extracts (50 $\mu \mathrm{g} /$ lane) from RN46A, SN48, SKN-SH, and NG108-15 cells were subjected to Western blot analysis using specific anti-Deaf- 1 antibody. The blot was reprobed using antibodies for markers of nuclear (histone-H1) and cytosolic (c-Raf) fractions to assess loading and purity of extracts. Molecular weight markers ( $\mathrm{kDa}$ ) are as indicated. $\boldsymbol{B}$, Deaf-1 DNA binding activity. Electrophoretic mobility shift assay was done using nuclear extracts from RN46A, SN48, or NG108-15 cells that were incubated with labeled 26$\mathrm{bp}(\mathrm{C})$ probe in the presence of 100 -fold molar excess of unlabeled $26 \mathrm{bp}(\mathrm{C})(\mathrm{Sp})$ or unrelated PEA3 (NSp) oligonucleotides, as indicated. A major specific Deaf-1 complex was observed (arrow).

between Deaf- 1 and Hes5 at the 26 bp $5-\mathrm{HT}_{1 \mathrm{~A}}$ palindrome. To address this, Deaf-1 and Hes5 were cotransfected in RN46A or SN48 cells, and transcriptional activity at the 26 bp palindrome was measured (Fig. 4). In RN46A cells, both Deaf-1 and Hes5
A

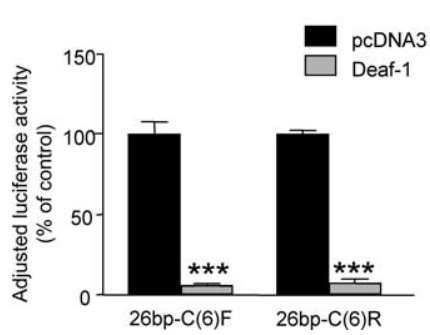

B

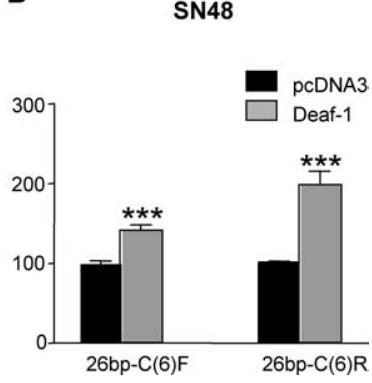

Figure 3. Orientation-independent repressor and enhancer activities of Deaf- 1 at the $5-\mathrm{HT}_{1 \mathrm{~A}}$ palindrome. In RN46A ( $\boldsymbol{A})$ or SN48 $(\boldsymbol{B})$ cells, luciferase reporter constructs containing six copies of the $26 \mathrm{bp} 5-\mathrm{HT}_{1 \mathrm{~A}}$ palindrome in the forward [26bp-C(6)F] or reverse orientation $[26 \mathrm{bp}-\mathrm{C}(6) \mathrm{R}]$ relative to the SV40 promoter were cotransfected with vector (pcDNA3) or Deaf-1 expression plasmid. Luciferase activity was normalized to vector control, and data are presented as mean \pm SD of triplicate samples collected from four independent experiments. Statistical analysis was performed by unpaired $t$ test with two-tailed $p$ values ( ${ }^{* * *} p \leq 0.001$ ).

repressed transcriptional activity, and together Deaf-1 and Hes5 induced a similar repression (Fig. 4A). In SN48 cells, Deaf-1 enhanced activity of the 26bp-C(6) construct, whereas Hes5 repressed its activity (Fig. $4 \mathrm{~B}$ ). Interestingly, when cotransfected with Hes5, Deaf-1-mediated enhancement was the dominant effect. A similar pattern was observed using the 5- $\mathrm{HT}_{1 \mathrm{~A}}$ promoterluciferase construct, with Deaf-1 enhancer activity dominant over Hes5 repression (Fig. 4C). Thus, the enhancer activity of Deaf- 1 could result from a competition with endogenous repressors such as Hes5.

\section{HDAC-dependent repressor/enhancer activity of Deaf-1}

Because recruitment of histone deacetylase (HDAC) is implicated in gene repression (Ayer, 1999), we tested the effect of HDAC inhibitor TSA on Deaf-1-mediated repressor or enhancer activity at the $5-\mathrm{HT}_{1 \mathrm{~A}}$ promoter (Fig. 5). We also tested the $5-\mathrm{HT}_{1 \mathrm{~A}}$ RE-1 element placed upstream of the SV40 promoter in the pGL3P vector (pGL3P-RE1), the target of the prototypic REST/NRSF that mediates TSA-sensitive repression (Lemonde et al., 2004a). In RN46A cells, Deaf-1 reduced 5-HT IA $_{\text {A }}$ promoter activity, and this action was attenuated by TSA treatment. Similarly, the silencer activity of REST at RE-1 was also partially reversed by TSA treatment in RN46A cells. In SN48 cells, Deaf-1induced enhancer activity was also inhibited by TSA, indicating that HDAC activity is also required for Deaf-1-mediated enhancer activity. In SN48 cells, TSA treatment reversed RESTmediated repression to enhanced activity compared with vector (pGL3P), consistent with the finding that REST can recruit silencer or enhancer activities (Jepsen et al., 2000). Thus Deaf-1mediated recruitment of HDAC can either repress or enhance $5-\mathrm{HT}_{1 \mathrm{~A}}$ promoter activity, depending on the cellular context.

\section{Intrinsic repressor/enhancer activity of Deaf-1}

Deaf-1-mediated repressor/enhancer activity could result from competition with other factors (e.g., Hes5) or represent an intrinsic property of Deaf- 1 . To test the latter possibility, a completely heterologous hybrid system was used: full-length Deaf-1 was fused to the Gal4 DNA binding domain (DBD) and its activity tested at a reporter construct containing Gal4 elements (Fig. 5A). Full-length Deaf-1 was used to preserve protein-protein interactions. Compared with the vector (Gal4DBD), Gal4DBD-Deaf-1 repressed the SV40 promoter in RN46A cells (Fig. 6), indicating that Deaf- 1 confers repression when recruited to a heterologous element and promoter. This effect was entirely blocked by TSA, 

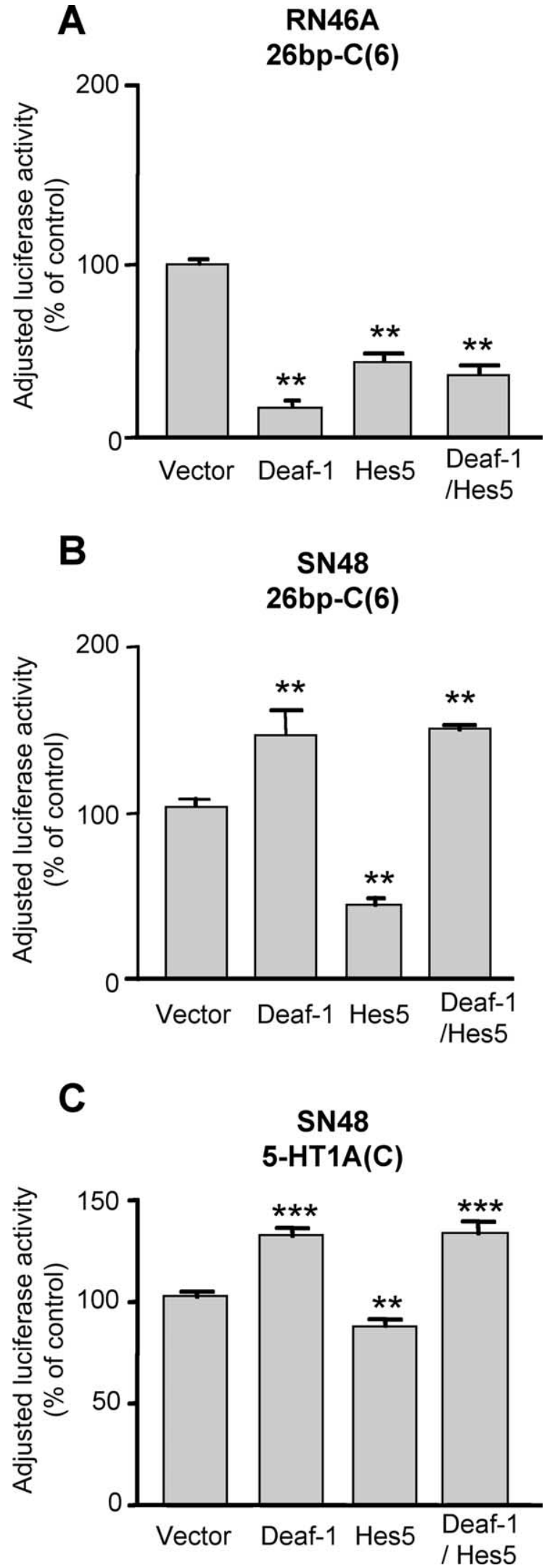

Figure 4. Deaf- 1 competes with Hes 5 to enhance $5-\mathrm{HT}_{1 \mathrm{~A}}$ promoter activity. The $26 \mathrm{bp}-\mathrm{C}(6)$ reporter construct [containing 6 copies of the $(-1019)$ allele of the $26 \mathrm{bp} 5-\mathrm{HT}_{1 \mathrm{~A}}$ palindrome] or the $5-\mathrm{HT}_{1 \mathrm{~A}}(\mathrm{C})$ promoter construct was cotransfected with vector (pcDNA3), Deaf-1, or Hes5 plasmids in RN46A cells $(\boldsymbol{A})$ or SN48 cells $(\boldsymbol{B}, \boldsymbol{C})$. Luciferase activity was normalized to control transfections. Data are presented as mean \pm SEM of triplicate samples from three separate experiments. Significance is compared with vector control as indicated $\left({ }^{* *} p<\right.$ $0.01 ; * * * 00.001)$.
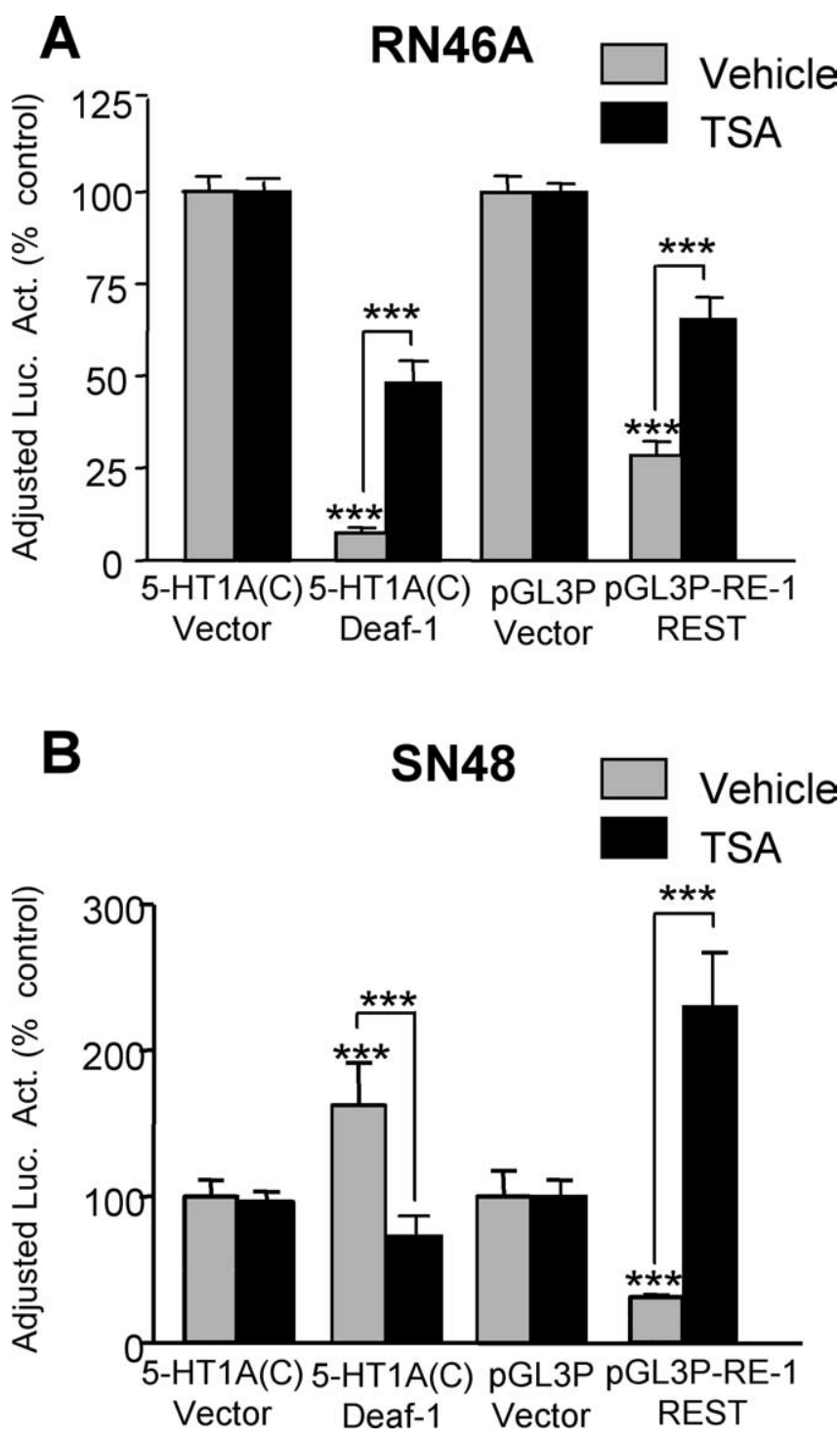

Figure 5. Repressor and enhancer activities of Deaf- 1 at the $5-\mathrm{HT}_{1 \mathrm{~A}}$ promoter are TSA sensitive. The -1128 bp $5-\mathrm{HT}_{1 \mathrm{~A}}$-luciferase construct $\left[5-\mathrm{HT}_{1 \mathrm{~A}}(\mathrm{C})\right]$ was cotransfected with vector (pCDNA3) or Deaf-1 plasmids in rat raphe RN46A and mouse septal SN-48 cells. As a positive control for TSA, a luciferase construct containing human 5- $\mathrm{HT}_{1 \mathrm{~A}}$ RE-1 placed 5' to SV40promoter was cotransfected with vector (pcDNA1) or REST plasmids. Cells were treated with vehicle or TSA (200 nm) for $24 \mathrm{~h}$, as indicated. Luciferase activity (Luc. Act.)/ $\beta$-galactosidase activity was normalized to control (vector) transfections. Data are presented as mean \pm SD of triplicate samples collected from at least three independent experiments, as indicated. Statistical analysis was determined by unpaired $t$ test with two-tailed $p$ values $\left({ }^{* * *} p \leq 0.001\right)$.

indicating that Deaf-1 repression is dependent on HDAC activation, whereas LexA-mediated repression was not reversed by TSA, as observed previously (Lemonde et al., 2004a). When transfected in SN48 cells, Gal4-Deaf-1 induced a small but significant enhancement of transcription that was inhibited to below basal activity by TSA, whereas LexA induced HDACindependent repression (Fig. 6C). The effect of TSA indicates a primary role for HDAC in Deaf- 1 enhancer activity and reveals a possible HDAC-independent Deaf-1 repressor activity. Thus Deaf-1-induced enhancer activity in SN48 cells is HDAC dependent and is conferred by Deaf- 1 itself and is not attributable to displacement of the binding of another repressor to the $26 \mathrm{bp}$ palindrome (such as Hes5). 
A

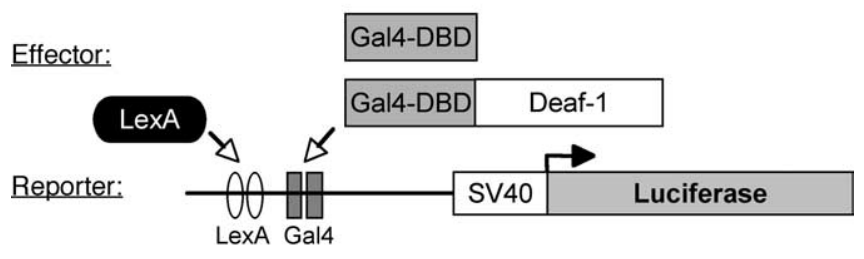

B

RN46A

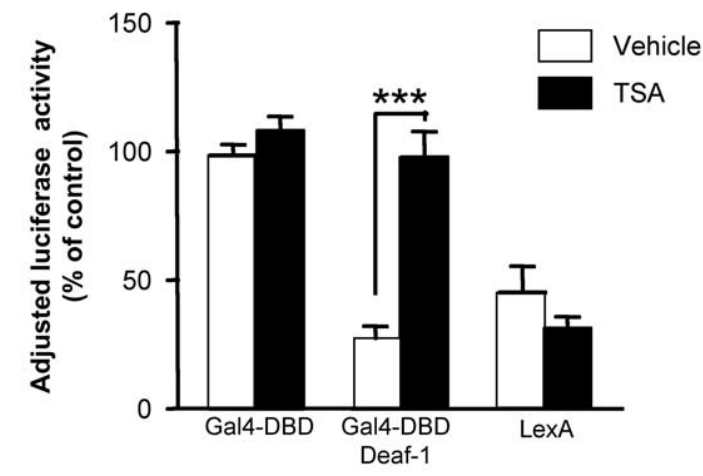

C

\section{SN48}

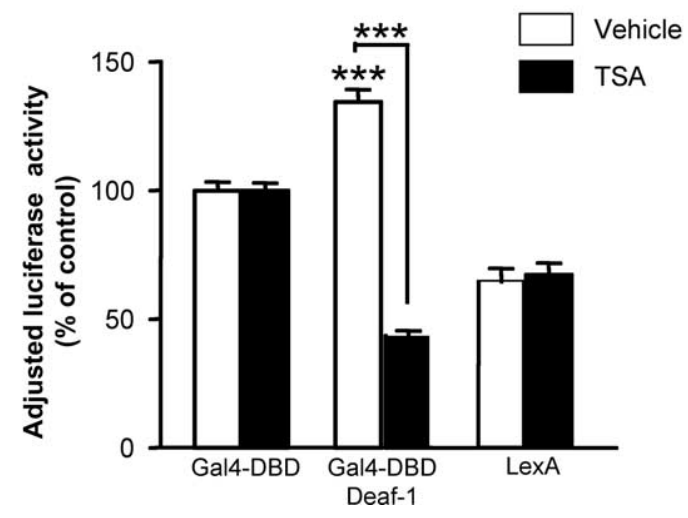

Figure 6. Cell-specific and TSA-sensitive repressor and enhancer activities are conferred by Deaf- 1 at a heterologous DNA element. A, A model for the action of effectors Gal4-DBD (Gal4 vector), Gal4DBD-Deaf-1 fusion protein, or LexA (positive control) at the X2G2P reporter construct containing two LexA and Gal4 sites upstream of SV40 promoter-luciferase. These constructs were cotransfected in 5- $\mathrm{HT}_{1 \mathrm{~A}}$-expressing rat RN46A (B) or mouse SN48 ( $(\boldsymbol{C})$ cells, which were treated for $24 \mathrm{~h}$ with vehicle or TSA ( $200 \mathrm{~nm}$ ). Luciferase activity was normalized to Gal4 vector $(100 \%)$. Data are presented as mean \pm SD of triplicate samples collected from at least two independent experiments as indicated. Statistical analysis was determined by unpaired $t$ test with two-tailed $p$ values $\left.{ }^{* * *} p \leq 0.001\right)$.

\section{Discussion}

Deaf-1, a cell-specific repressor or enhancer

In this study, we show that Deaf-1 binds to the C(-1019) site to repress $5-\mathrm{HT}_{1 \mathrm{~A}}$ receptor gene transcription in a presynaptic serotonergic cell line (RN46A), whereas Deaf-1 enhanced transcription in postsynaptic neuronal or glial cells (SN48, NG108-15, SKN-SH), as shown in the model (Fig. 1) (supplemental material, available at www.jneurosci.org). The finding that the $\mathrm{G}(-1019)$ allele blocked both enhancer and repressor actions of Deaf-1 argues for a direct effect of Deaf-1 at the 5- $\mathrm{HT}_{1 \mathrm{~A}}$ promoter. Hes5mediated repression in all cell lines, which was attenuated in postsynaptic models by the presence of Deaf-1-mediated enhancer activity. This suggests that Deaf-1 and Hes5 compete for binding to the 26 bp palindrome, but that Deaf- 1 may have higher affinity for binding than Hes5. However, Deaf-1-induced enhancement did not result from competition with an endogenous stronger repressor of the $26 \mathrm{bp} 5-\mathrm{HT}_{1 \mathrm{~A}}$ palindrome element, because cell-specific Deaf- 1 enhancer activity was present in the heterologous GAL4-DBD system. The possibility that differences in activator or repressor activity result from competition with binding to endogenous promoters is unlikely, because the number of genomic sites for Deaf-1 is at least 100-fold lower than that of transfected reporter construct, based on $10 \%$ transfection efficiency. We postulate that Deaf- 1 recruits cell-specific protein complexes to the DNA to either repress or enhance transcription.

\section{Multiple trans-acting functions of Deaf- 1}

Deaf-1 has been shown previously to have either repressor or enhancer function depending on the gene analyzed. NUDR is the human homolog of Deaf-1, a DNA-binding protein that was first shown to bind the autoregulatory element of the deformed gene in Drosophila melanogaster (Gross and McGinnis, 1996). In these studies, Deaf-1 synergistically activated deformed protein autoregulation of the $120 \mathrm{bp}$ deformed response element, thus displaying enhancer activity. Human Deaf- 1 trans-activated preproenkephalin promoter activity by 30 -fold, but this effect appeared to be independent of DNA binding to the promoter (Huggenvik et al., 1998). However, in monkey kidney CV-1 cells, Deaf-1 repressed the hnRNP A2/B1 and Deaf-1 promoters via sites located downstream from transcriptional initiation (Michelson et al., 1999). In contrast to these studies in different genes, depending on the cell type Deaf-1 repressed or enhanced gene transcription at the same $\mathrm{C}(-1019)$ site of the $5-\mathrm{HT}_{1 \mathrm{~A}}$ receptor gene. This Deaf- 1 site conferred cell-specific regulation at a heterologous promoter, implying that Deaf- 1 recruits cell-specific regulatory factors to repress or enhance transcription.

Different functional domains within Deaf- 1 could mediate its enhancer or repressor activities. The structure of Deaf- 1 includes the conserved DNA-binding SAND domain (Sp100, AIRE-1, NucP41/75, Deaf-1) and a C-terminal MYND (myeloid, nervy, and Deaf-1) domain (Gross and McGinnis, 1996). Deaf-1 also contains two protein-interaction domains for its interaction with both LIM-only (LMO4) and nuclear LIM-binding protein (NLI/ CLIM) transcriptional regulators, which mediate embryonic pattern formation and cell fate (Sum et al., 2002). Deaf-1-null mice display phenotypic abnormalities, including exencephaly and transformation of cervical segments that resemble those of LMO4-null mice, further suggesting functional overlap between Deaf- 1 and LMO4 (Hahm et al., 2004; Tse et al., 2004; Lee et al., 2005). LMO4 has been shown to recruit various NLI proteins that lead to transcriptional activation or repression (Bach et al., 1997; Jurata and Gill, 1997). Therefore, recruitment by Deaf-1 of different protein complexes could direct enhancement or repression of gene transcription.

Deaf- 1 also contains both nuclear import (Jensik et al., 2004) and export sites (Huggenvik et al., 1998) to regulate trafficking. The finding that nuclear Deaf- 1 content is greatest in RN46A cells (Fig. 2A) suggests that Deaf-1 may be stabilized in the nucleus (perhaps in heterochromatin) to exert its repressor activity. We observed little effect of the $\mathrm{C}(-1019) \mathrm{G}$ mutation on basal activity of $5-\mathrm{HT}_{1 \mathrm{~A}}$ reporter constructs in RN46A cells (Fig. 1A), where endogenous Deaf-1 may be bound to the endogenous $5-\mathrm{HT}_{1 \mathrm{~A}}$ gene and inaccessible to the reporter construct. Yet, there was a clear effect of the C(-1019)G change on basal activity in postsyn- 
aptic cells where Deaf- 1 is mostly cytosolic and may be free to translocate to the reporter construct. At reporter constructs, transfected Deaf-1 displayed greater repressor activity than enhancer activity (Figs. 3, 4), because the background activity of endogenous Deaf- 1 to repress is lower than basal enhancer activity (Fig. 1, compare $A$ and $B$ ). Therefore, the preferential localization of Deaf- 1 in the nucleus of RN46A cells appears to correlate with its greater activity as a repressor.

\section{HDAC dependence of Deaf-1 function}

Both repressor and enhancer activities of Deaf-1 were blocked by inhibition of HDAC using the HDAC-specific (class I and II) inhibitor TSA (Yoshida et al., 1990), implicating HDAC in these activities of Deaf-1. HDACs regulate the acetylation of histone and nonhistone proteins, as well as the recruitment of transcriptional regulatory protein complexes to chromatin (Yang, 2004). In addition to their roles in transcriptional repression, deacetylases can also positively regulate gene expression by deacetylation of transcription factors (Yang and Gregoire, 2005). For example, recruitment of HDAC by STAT5 (signal transducer and activator of transcription 5) proteins leads to deacetylation of $\mathrm{C} / \mathrm{EBP} \beta$ (CCAAT/enhancer-binding protein $\beta$ ), resulting in transcriptional activation of the Id-1 repressor gene (Xu et al., 2003). Therefore, TSA-mediated inhibition of HDAC activity can block repression as well as enhancer activity.

Deaf-1 provides an unusual example of a transcription factor that, after directly binding to the same DNA regulatory element, can recruit HDAC-dependent mechanisms to either repress or enhance gene expression. Transcription factors, such as nuclear receptors or myocyte enhancer factor-2, can function as repressor or enhancer but repressor activity involves recruitment of HDAC, whereas enhancer activity requires recruitment of histone acetylase activity and the absence of HDAC (Glass and Rosenfeld, 2000; McKinsey et al., 2001). Alternately, enhancer activity can be mediated through indirect protein-protein interactions. For example, REST can both repress corticotrophin releasing hormone gene expression by binding to its RE-1 element and enhance its transcription via a mechanism independent of RE-1 in NG108-15 cells (Seth and Majzoub, 2001). Generally, REST represses most target genes by association with corepressors including $\operatorname{Sin} 3 \mathrm{~A}$, nuclear receptor corepressor ( $\mathrm{NCoR})$, or CoREST. However, the corepressor NCoR can mediate HDACdependent gene activation (Jepsen et al., 2000), a mechanism that could account for the HDAC-dependent activation of the 5- $\mathrm{HT}_{1 \mathrm{~A}}$ gene in postsynaptic cells by Deaf-1.

\section{Implications for depression}

Identifying mechanisms that control $5-\mathrm{HT}_{1 \mathrm{~A}}$ receptor expression has strong clinical relevance, because the $5-\mathrm{HT}_{1 \mathrm{~A}}$ receptor is a major direct or indirect target of antidepressant drugs (Pineyro and Blier, 1999; Blier and Ward, 2003; Albert and Lemonde, 2004). An increase in $5-\mathrm{HT}_{1 \mathrm{~A}}$ autoreceptor expression has been associated with major depression (Stockmeier et al., 1998). In normal subjects and especially unmedicated depressed subjects, in vivo imaging studies reveal increased $5-\mathrm{HT}_{1 \mathrm{~A}}$ autoreceptors in the raphe area in $\mathrm{G} / \mathrm{G}$ versus non-G/G genotype, consistent with de-repression of Deaf-1 at the 5-HT ${ }_{1 \mathrm{~A}}$ G-allele (David et al., 2005; Parsey et al., 2006). Postsynaptically, however, subjects with major depressive or panic disorder have a significant decrease in 5- $\mathrm{HT}_{1 \mathrm{~A}}$ mRNA (Lopez-Figueroa et al., 2004) and decreased $5-\mathrm{HT}_{1 \mathrm{~A}}$ receptor levels in hippocampus and cortex (Sargent et al., 2000; Bhagwagar et al., 2004; Neumeister et al., 2004). Furthermore, after chronic antidepressant treatment, $5-\mathrm{HT}_{1 \mathrm{~A}}$ autorecep- tors are preferentially desensitized, whereas postsynaptic $5-\mathrm{HT}_{1 \mathrm{~A}}$ receptors are not (Pineyro and Blier, 1999). The cell-specific function of Deaf- 1 could underlie differential regulation of presynaptic and postsynaptic $5-\mathrm{HT}_{1 \mathrm{~A}}$ receptor expression in vivo (Fig. 1) (supplemental material, available at www.jneurosci.org). The G/G genotype could confer de-repression of the 5- $\mathrm{HT}_{1 \mathrm{~A}}$ gene in the raphe but reduced Deaf- 1 enhancer activity in postsynaptic neurons. The extent of Deaf-1 enhancer activity varied depending on the cell type, with strongest activity in septal SN48 cells. By analogy, the contribution of Deaf- 1 to $5-\mathrm{HT}_{1 \mathrm{~A}}$ receptor expression in various brain regions and the influence of the C(-1019)G genotype will differ depending on the neuronal cell type.

In summary, we identified a novel HDAC-dependent regulatory mechanism by which Deaf-1 mediates cell-specific enhancer or repressor activity to regulate the $5-\mathrm{HT}_{1 \mathrm{~A}}$ receptor gene. These divergent regulatory mechanisms by Deaf-1 may confer differential regulation of the $5-\mathrm{HT}_{1 \mathrm{~A}}$ receptor in presynaptic versus postsynaptic brain regions in vivo.

\section{References}

Albert PR, Lemonde S (2004) 5- $\mathrm{HT}_{1 \mathrm{~A}}$ receptors, gene repression, and depression: guilt by association. Neuroscientist 10:575-593.

Ansorge M, Tanneberger C, Davies B, Theuring F, Kusserow H (2004) Analysis of the murine 5-HT receptor gene promoter in vitro and in vivo. Eur J Neurosci 20:363-374.

Ayer DE (1999) Histone deacetylases: transcriptional repression with SINers and NuRDs. Trends Cell Biol 9:193-198.

Bach I, Carriere C, Ostendorff HP, Andersen B, Rosenfeld MG (1997) A family of LIM domain-associated cofactors confer transcriptional synergism between LIM and Otx homeodomain proteins. Genes Dev 11:1370-1380.

Bayliss DA, Li YW, Talley EM (1997) Effects of serotonin on caudal raphe neurons: activation of an inwardly rectifying potassium conductance. J Neurophysiol 77:1349-1361.

Bhagwagar Z, Rabiner EA, Sargent PA, Grasby PM, Cowen PJ (2004) Persistent reduction in brain serotonin $1 \mathrm{~A}$ receptor binding in recovered depressed men measured by positron emission tomography with [11C]WAY-100635. Mol Psychiatry 9:386-392.

Blier P, Ward NM (2003) Is there a role for 5-HT(1A) agonists in the treatment of depression? Biol Psychiatry 53:193-203.

Brown KA, Roberts RL, Arteaga CL, Law BK (2004) Transforming growth factor-beta induces $\mathrm{Cdk} 2$ relocalization to the cytoplasm coincident with dephosphorylation of retinoblastoma tumor suppressor protein. Breast Cancer Res 6:R130-R139.

Charest A, Wainer BH, Albert PR (1993) Cloning and differentiationinduced expression of a murine serotonin $1 \mathrm{~A}$ receptor in a septal cell line. J Neurosci 13:5164-5171.

David SP, Murthy NV, Rabiner EA, Munafo MR, Johnstone EC, Jacob R, Walton RT, Grasby PM (2005) A functional genetic variation of the serotonin (5-HT) transporter affects $5-\mathrm{HT}_{1 \mathrm{~A}}$ receptor binding in humans. J Neurosci 25:2586-2590.

Drevets WC, Frank E, Price JC, Kupfer DJ, Holt D, Greer PJ, Huang Y, Gautier C, Mathis C (1999) PET imaging of serotonin 1A receptor binding in depression. Biol Psychiatry 46:1375-1387.

Fricker AD, Rios C, Devi LA, Gomes I (2005) Serotonin receptor activation leads to neurite outgrowth and neuronal survival. Brain Res Mol Brain Res 138:228-235.

Glass CK, Rosenfeld MG (2000) The coregulator exchange in transcriptional functions of nuclear receptors. Genes Dev 14:121-141.

Gross C, Zhuang X, Stark K, Ramboz S, Oosting R, Kirby L, Santarelli L, Beck S, Hen R (2002) Serotonin1A receptor acts during development to establish normal anxiety-like behaviour in the adult. Nature 416:396-400.

Gross CT, McGinnis W (1996) DEAF-1, a novel protein that binds an essential region in a deformed response element. EMBO J 15:1961-1970.

Hahm K, Sum EY, Fujiwara Y, Lindeman GJ, Visvader JE, Orkin SH (2004) Defective neural tube closure and anteroposterior patterning in mice lacking the LIM protein LMO4 or its interacting partner Deaf-1. Mol Cell Biol 24:2074-2082.

Huggenvik JI, Michelson RJ, Collard MW, Ziemba AJ, Gurley P, Mowen KA (1998) Characterization of a nuclear deformed epidermal autoregulatory 
factor-1 (DEAF-1)-related (NUDR) transcriptional regulator protein. Mol Endocrinol 12:1619-1639.

Jacobs BL, Azmitia EC (1992) Structure and function of the brain serotonin system. Physiol Rev 72:165-229.

Jensik PJ, Huggenvik JI, Collard MW (2004) Identification of a nuclear export signal and protein interaction domains in deformed epidermal autoregulatory factor-1 (DEAF-1). J Biol Chem 279:32692-32699.

Jepsen K, Hermanson O, Onami TM, Gleiberman AS, Lunyak V, McEvilly RJ, Kurokawa R, Kumar V, Liu F, Seto E, Hedrick SM, Mandel G, Glass CK, Rose DW, Rosenfeld MG (2000) Combinatorial roles of the nuclear receptor corepressor in transcription and development. Cell 102:753-763.

Jurata LW, Gill GN (1997) Functional analysis of the nuclear LIM domain interactor NLI. Mol Cell Biol 17:5688-5698.

Kushwaha N, Albert PR (2005) Coupling of 5- $\mathrm{HT}_{1 \mathrm{~A}}$ autoreceptors to inhibition of mitogen-activated protein kinase activation via Gbetagamma subunit signaling. Eur J Neurosci 21:721-732.

Lee SK, Jurata LW, Nowak R, Lettieri K, Kenny DA, Pfaff SL, Gill GN (2005) The LIM domain-only protein LMO4 is required for neural tube closure. Mol Cell Neurosci 28:205-214.

Lemonde S, Turecki G, Bakish D, Du L, Hrdina PD, Bown CD, Sequeira A, Kushwaha N, Morris SJ, Basak A, Ou XM, Albert PR (2003) Impaired repression at a 5-hydroxytryptamine $1 \mathrm{~A}$ receptor gene polymorphism associated with major depression and suicide. J Neurosci 23:8788-8799.

Lemonde S, Rogaeva A, Albert PR (2004a) Cell type-dependent recruitment of trichostatin A-sensitive repression of the human $5-\mathrm{HT}_{1 \mathrm{~A}}$ receptor gene. J Neurochem 88:857-868.

Lemonde S, Du L, Bakish D, Hrdina P, Albert PR (2004b) Association of the $\mathrm{C}(-1019) \mathrm{G} 5-\mathrm{HT}_{1 \mathrm{~A}}$ functional promoter polymorphism with antidepressant response. Int J Neuropsychopharmacol 7:501-506.

Lopez-Figueroa AL, Norton CS, Lopez-Figueroa MO, Armellini-Dodel D, Burke S, Akil H, Lopez JF, Watson SJ (2004) Serotonin 5-HT ${ }_{1 \mathrm{~A}}, 5-\mathrm{HT}_{1 \mathrm{~B}}$, and $5-\mathrm{HT}_{2 \mathrm{~A}}$ receptor mRNA expression in subjects with major depression, bipolar disorder, and schizophrenia. Biol Psychiatry 55:225-233.

McKinsey TA, Zhang CL, Olson EN (2001) Control of muscle development by dueling HATs and HDACs. Curr Opin Genet Dev 11:497-504.

Michelson RJ, Collard MW, Ziemba AJ, Persinger J, Bartholomew B, Huggenvik JI (1999) Nuclear DEAF-1-related (NUDR) protein contains a novel DNA binding domain and represses transcription of the heterogeneous nuclear ribonucleoprotein A2/B1 promoter. J Biol Chem 274:30510-30519.

Neumeister A, Bain E, Nugent AC, Carson RE, Bonne O, Luckenbaugh DA, Eckelman W, Herscovitch P, Charney DS, Drevets WC (2004) Reduced serotonin type $1 \mathrm{~A}$ receptor binding in panic disorder. J Neurosci 24:589-591.

Ou XM, Jafar-Nejad H, Storring JM, Meng JH, Lemonde S, Albert PR (2000) Novel dual repressor elements for neuronal cell-specific transcription of the rat 5- $\mathrm{HT}_{1 \mathrm{~A}}$ receptor gene. J Biol Chem 275:8161-8168.

Parsey RV, Oquendo MA, Ogden RT, Olvet DM, Simpson N, Huang YY, Van Heertum RL, Arango V, Mann JJ (2006) Altered serotonin 1A binding in major depression: a [carbonyl-C-11]WAY100635 positron emission tomography study. Biol Psychiatry, in press.

Penington NJ, Kelly JS, Fox AP (1993) Whole-cell recordings of inwardly rectifying $\mathrm{K}^{+}$currents activated by $5-\mathrm{HT}_{1 \mathrm{~A}}$ receptors on dorsal raphe neurones of the adult rat. J Physiol (Lond) 469:387-405.
Pineyro G, Blier P (1999) Autoregulation of serotonin neurons: role in antidepressant drug action. Pharmacol Rev 51:533-591.

Sargent PA, Kjaer KH, Bench CJ, Rabiner EA, Messa C, Meyer J, Gunn RN, Grasby PM, Cowen PJ (2000) Brain serotonin1A receptor binding measured by positron emission tomography with [11C]WAY-100635: effects of depression and antidepressant treatment. Arch Gen Psychiatry 57:174-180.

Serretti A, Artioli P, Lorenzi C, Pirovano A, Tubazio V, Zanardi R (2004) The C(-1019)G polymorphism of the 5-HT1A gene promoter and antidepressant response in mood disorders: preliminary findings. Int J Neuropsychopharmacol 7:453-460.

Seth KA, Majzoub JA (2001) Repressor element silencing transcription factor/neuron-restrictive silencing factor (REST/NRSF) can act as an enhancer as well as a repressor of corticotropin-releasing hormone gene transcription. J Biol Chem 276:13917-13923.

Stockmeier CA, Shapiro LA, Dilley GE, Kolli TN, Friedman L, Rajkowska G (1998) Increase in serotonin-1A autoreceptors in the midbrain of suicide victims with major depression-postmortem evidence for decreased serotonin activity. J Neurosci 18:7394-7401.

Strobel A, Gutknecht L, Rothe C, Reif A, Mossner R, Zeng Y, Brocke B, Lesch KP (2003) Allelic variation in 5-HT(1A) receptor expression is associated with anxiety- and depression-related personality traits. J Neural Transm 110:1445-1453.

Subramanian T, Chinnadurai G (2003) Association of class I histone deacetylases with transcriptional corepressor CtBP. FEBS Lett 540:255-258.

Sum EY, Peng B, Yu X, Chen J, Byrne J, Lindeman GJ, Visvader JE (2002) The LIM domain protein LMO4 interacts with the cofactor CtIP and the tumor suppressor BRCA1 and inhibits BRCAl activity. J Biol Chem 277:7849-7856.

Törk I (1990) Anatomy of the serotonergic system. Ann NY Acad Sci 600:9-35.

Tse E, Smith AJ, Hunt S, Lavenir I, Forster A, Warren AJ, Grutz G, Foroni L, Carlton MB, Colledge WH, Boehm T, Rabbitts TH (2004) Null mutation of the Lmo4 gene or a combined null mutation of the Lmo1/Lmo3 genes causes perinatal lethality, and Lmo4 controls neural tube development in mice. Mol Cell Biol 24:2063-2073.

Xu M, Nie L, Kim SH, Sun XH (2003) STAT5-induced Id-1 transcription involves recruitment of $\mathrm{HDAC} 1$ and deacetylation of C/EBPbeta. EMBO J 22:893-904.

Yang XJ (2004) Lysine acetylation and the bromodomain: a new partnership for signaling. BioEssays 26:1076-1087.

Yang XJ, Gregoire S (2005) Class II histone deacetylases: from sequence to function, regulation, and clinical implication. Mol Cell Biol 25:2873-2884.

Yoshida M, Kijima M, Akita M, Beppu T (1990) Potent and specific inhibition of mammalian histone deacetylase both in vivo and in vitro by trichostatin A. J Biol Chem 265:17174-17179.

Zuccato C, Tartari M, Crotti A, Goffredo D, Valenza M, Conti L, Cataudella T, Leavitt BR, Hayden MR, Timmusk T, Rigamonti D, Cattaneo E (2003) Huntingtin interacts with REST/NRSF to modulate the transcription of NRSE-controlled neuronal genes. Nat Genet 35:76-83. 